\title{
Effects of Dietary Alkyl Polyglycoside Supplementation on Lactation Performance, Blood Parameters and Nutrient Digestibility in Dairy Cows
}

\author{
Xiaoli Zhang ${ }^{1,2,+} \oplus$, Chunyu Jiang ${ }^{3,+}$, Qinghua Gao ${ }^{3}$, Duanqin $W_{u}{ }^{1}$, Shaoxun Tang ${ }^{1,4}$, \\ Zhiliang Tan ${ }^{1,4}$ and Xuefeng Han $1,5, *$ (D) \\ 1 Key Laboratory for Agro-Ecological Processes in Subtropical Region, National Engineering Laboratory for \\ Pollution Control and Waste Utilization in Livestock and Poultry Production, South Central Experimental \\ Station of Animal Nutrition and Feed Science in the Ministry of Agriculture, Institute of Subtropical \\ Agriculture, The Chinese Academy of Sciences, Changsha, Hunan 410125, China \\ 2 College of Advanced Agricultural Sciences, University of the Chinese Academy of Sciences, Beijing 100049, \\ China \\ 3 Key Laboratory of Animal Husbandry Science and Technology of Xinjiang Production and Construction \\ Corps, College of Animal Science, Tarim University, Alar, Xinjiang 843300, China \\ 4 Hunan Co-Innovation Center of Animal Production Safety, CICAPS, Changsha, Hunan 410128, China \\ 5 Hunan Co-Innovation Center for Utilization of Botanical Functional Ingredients, Changsha 410128, China \\ * Correspondence: xfhan@isa.ac.cn; Tel.: +86-731-8461-5218 \\ + This author contributed equally to this work as co-first author.
}

Received: 24 June 2019; Accepted: 7 August 2019; Published: 13 August 2019

Simple Summary: This project investigated the effects of alkyl polyglycoside (APG), a non-ionic surfactant, on lactation performance, blood metabolites and nutrient digestibility of lactating dairy cows, and found that the addition of APG at doses up to $22 \mathrm{~mL} / \mathrm{kg}$ of pelleted concentrate (around $9 \mathrm{~mL} / \mathrm{kg}$ of diet or $100 \mathrm{~mL} /$ day/head) had positive effects on milk quality in dairy cows.

Abstract: This study evaluated the effects of alkyl polyglycoside (APG), which is a non-ionic surfactant, on lactation performance, nutrient digestibility and blood metabolites in dairy cows. Twenty dairy cows were randomly divided into four groups and fed a basal diet that included pelleted concentrate, distillers grains, and fresh limpograss. The four treatments included 0, 5.5, 11 and $22 \mathrm{~mL}$ APG per $\mathrm{kg}$ of pelleted concentrate on a dry matter basis; treatments were defined as APG0, APG5.5, APG11, and APG22, respectively. Dry matter intake was not affected by APG supplementation. There was an increase in milk yield (from 13.96 to $16.71 \mathrm{~kg} /$ day) and increases in milk fat (quadratic, $p=0.04$ ), protein (quadratic, $p=0.10$ ), and lactose concentrations (linear, $p=0.07$ ) with increasing APG supplementation. In addition, APG supplementation increased $(p \leq 0.03)$ the milk fat, protein, solid non-fat, and total solid yields, while the lactose yield increased (linear, $p=0.01$ ) as the APG level increased. Dietary APG supplementation had no effect on nutrient digestibility and blood metabolites. It was concluded that the addition of APG at doses up to $22 \mathrm{~mL} / \mathrm{kg}$ of pelleted concentrate had positive effects on the milk composition in dairy cows.

Keywords: APG; lactation performance; blood metabolites; digestibility; dairy cow

\section{Introduction}

Surfactants can increase the rate of hydrolysis of Sigmacell 100 cellulose and steam-exploded wood [1]. The enhancement of fibrolytic activity by surfactants can involve various mechanisms. In the cellulolytic ascomycete Neurospora crassa, Tween 80 stimulated the release of both endoglucanase and 
exoglucanase [2]. Kim et al. [3] also showed that surfactants can prevent the deactivation of cellulases, prolonging their lifespan.

In rumen cultures, surfactants have been found to enhance fibrolysis [4]. However, Hristov et al. [5] did not observe effects of Tween 80 on carboxymethyl cellulase or xylanase activities. Kim et al. [6] found that Tween 80 increased the total volatile fatty acid (VFA) concentration and carboxymethyl cellulose activity and increased or tended to increase the total tract digestibility of crude fibre (CF) and ether extract (EE) in Hanwoo steers.

Alkyl polyglycoside (APG) is a naturally produced, environmentally friendly, non-ionic surfactant (NIS) resulting from the reaction of glucose with long chain fatty alcohols [7]. Moreover, APG has also been utilized in detergents as well as drug delivery, food processing, and agrochemistry processes [8-11] owing to its low toxicity and good biological degradability. Our previous study showed that APG supplementation increased in vitro rumen gas production and dry matter (DM) and organic matter $(\mathrm{OM})$ degradation of low-quality roughages [12]. Dietary APG supplementation increased OM intake and the digestibility of neutral detergent fibre (NDF) and acid detergent fibre (ADF) in goats [13]. Dietary APG supplementation affected the amino acid composition of the rumen content in goats [14]. To our knowledge, there is no information on the use of APG as additive supplement to dairy cow diets, even though data showed that poloxalene, a NIS, had no effect on the yield or composition of milk $[15,16]$. It is hypothesized that the APG supplementation could increase the nutrient digestibility, and then affect lactating performance of middle- and low-yielding dairy cows. The objective of this study was to characterize the responses of milk yield and composition, nutrient digestibility and blood metabolites to dietary APG supplementation in lactating dairy cows.

\section{Materials and Methods}

The Laboratory Animal Welfare and Animal Experimental Ethical Inspection Committee at the Institute of Subtropical Agriculture, Chinese Academy of Sciences reviewed and approved all protocols used in this study. The ethic code is No. ISA000185. The animal trials were conducted at the experimental farm of the Institute of Subtropical Agriculture (Changsha, China).

\subsection{Animals Experimental Design and Diets}

Twenty Holstein dairy cows, at $167 \pm 69$ days in milk, $480 \pm 55 \mathrm{~kg}$ body weight and $14.1 \pm 2.16 \mathrm{~kg} / \mathrm{day}$ milk yield (mean $\pm \mathrm{SD}$ ), were randomly assigned to four groups (APG0, APG5.5, APG11, and APG22) that were supplemented with 4 levels of APG: 0, 5.5, 11 and $22 \mathrm{~mL}$ per pelleted concentrate (on a DM basis), respectively. The APG supplementation levels and methods referred to Yuan et al. [13]. The pre-experimental treatment adaptation time was 7 days, and the experiment lasted for 60 days. Cows were housed and fed individually in tie stalls with free access to clean water throughout the experiment. Each cow received $5 \mathrm{~kg}(4.5 \mathrm{~kg} \mathrm{DM})$ pelleted concentrate and $9 \mathrm{~kg}(2.1 \mathrm{~kg} \mathrm{DM})$ distillers grains daily, and a sufficient amount of fresh limpograss (Hemarthria altissima) was fed to each cow every day. The pelleted concentrate, distillers grains, and limpograss were fed separately, and equally and successively offered twice a day at 07:00 and 18:00. For each feeding, the distillers grains was offered after pelleted concentrate was eaten up, and then limpograss was fed after distillers grains was finished. The APG (appearing as a colourless to pale yellow liquid, with 8-10 carbon alkyl chains, $70 \%$ solid content and a hydrophilic-lyophilic balance of 13-15, provided by Jinmoer Chemical Co., Ltd., Shijiazhuang, China) was mixed by hand with pelleted concentrate before every feeding. This amount of pelleted concentrate and distillers grains were always completely eaten by each cow during the entire experimental phase, and fresh limpograss offered to and refused by an individual animal was recorded daily. The formula of the pelleted concentrate and chemical compositions of the diet are shown in Table 1. 
Table 1. Ingredients and chemical compositions of the experimental diets.

\begin{tabular}{cccc}
\hline Composition (\% DM) ${ }^{\mathbf{1}}$ & Concentrate & Distillers Grains & Forage Grass \\
\hline Ingredients & & & \\
Corn & 52.5 & & \\
Wheat bran & 11.9 & & \\
Soybean meal & 16.2 & & \\
Cotton meal & 8.2 & & \\
Rapeseed meal & 5.0 & & \\
Calcium carbonate & 1.7 & & \\
Calcium hydrophosphate & 1.1 & & \\
Sodium chloride & 1.1 & 100 & \\
Mineral and vitamin mix & 2.3 & & \\
Distillers grains & & & \\
Limpograss & & 23.0 & 25.5 \\
Chemical compositions & & 39.8 & 11.5 \\
DM & 90.4 & 12.9 & 8.96 \\
CP & 22.9 & 3.74 & 68.5 \\
EE & 2.97 & 37.5 & 37.3 \\
Crude ash & 6.77 & 14.9 & 0.20 \\
NDF & 27.7 & 0.05 & 0.11 \\
ADF & 14.4 & 0.15 & \\
Ca & 0.78 & & \\
P & 0.46 & & \\
\hline
\end{tabular}

${ }^{1} \mathrm{DM}=$ dry matter; $\mathrm{CP}=$ crude protein; $\mathrm{EE}=$ ether extract; $\mathrm{NDF}=$ neutral detergent fibre; $\mathrm{ADF}=$ acid detergent fibre; $\mathrm{Ca}=$ calcium; $\mathrm{P}=$ phosphorus. ${ }^{2}$ Mineral and vitamin premix contained $3170 \mathrm{mg} / \mathrm{kg} \mathrm{Fe}, 14,280 \mathrm{mg} / \mathrm{kg} \mathrm{Zn,} 3060 \mathrm{mg} / \mathrm{kg}$ $\mathrm{Mn}, 3040 \mathrm{mg} / \mathrm{kg} \mathrm{Cu}, 40 \mathrm{mg} / \mathrm{kg} \mathrm{Co}, 180 \mathrm{mg} / \mathrm{kg} \mathrm{I}, 100 \mathrm{mg} / \mathrm{kg} \mathrm{Se}, 1,250,000 \mathrm{IU} / \mathrm{kg}$ vitamin A, 270,000 IU/kg vitamin D, and $5,000 \mathrm{IU} / \mathrm{kg}$ vitamin $\mathrm{E}$.

\subsection{Sample Collection and Processing}

Cows were milked twice daily at 05:00 and 16:00. Individual milk yield was recorded daily. Milk samples were collected in a plastic bottle containing potassium dichromate at morning and afternoon milking sessions for two consecutive days every 20 days and combined according to the corresponding volume measured at each milking session. Milk samples were kept refrigerated $\left(4^{\circ} \mathrm{C}\right)$ and transported to the laboratory for milk composition analysis as soon as possible.

Blood samples were collected from the coccygeal vein of each cow before the afternoon milking on the 20th, 40th, and 60th days of the experimental period. Blood was collected into a vacuum serum tube ( $5 \mathrm{~mL}$, Aosaite Medical Instrument Co., Ltd., Heze, China). Serum was separated by centrifugation at $3000 \times \mathrm{g}$ for $15 \mathrm{~min}$ and stored at $-20^{\circ} \mathrm{C}$ until analysis.

Feed samples were collected every 10 days, weighed and dried at $65^{\circ} \mathrm{C}$ for $48 \mathrm{~h}$, and then stored in a freezer until analysis. The amount of feed offered and refused was recorded while total faeces were collected daily for the last six consecutive days. The total collection of faeces at spontaneous defecation was performed using separate pans for each animal. The faeces in each container were weighed daily, and then a $10 \%$ aliquot of total faecal output was subsampled and frozen $\left(-20^{\circ} \mathrm{C}\right)$. The subsamples were later thawed and mixed to obtain one pooled sample from each animal. Each of these pooled samples was dried at $65^{\circ} \mathrm{C}$ for $48 \mathrm{~h}$ and then analysed for estimation of digestibility.

\subsection{Chemical Analyses}

Milk samples were analysed for fat, protein, lactose, solid non-fat (SNF) and total solid (TS) contents (Foss Milko-Scan134A/B, Foss Electric, Hillerod, Denmark).

The serum concentrations of glucose (GLU), blood urea nitrogen (BUN), ammonia (AMM), $\beta$-hydroxybutyric acid (BHB), triglyceride (TG), cholesterol (TC), high-density lipoprotein cholesterol (HDL-C), and low-density lipoprotein cholesterol (LDL-C) concentrations were determined using an automatic biochemical analyser (Mindray BS-300, Mindray Medical International Limited, Shenzhen, China).

The standard method of the Association of Official Analytical Chemists (AOAC) [17] was followed to determine the proximate chemical compositions of diets and faeces. Ground samples of feed and faeces were analysed for DM by drying at $105^{\circ} \mathrm{C}$. Crude ash was determined by heating at $550{ }^{\circ} \mathrm{C}$. 
Crude protein $(\mathrm{CP}=\mathrm{N} \times 6.25)$ was determined by the Kjeldahl method. EE was analysed using an automatic extraction apparatus (SOX416, C. Gerhardt GmbH \& Co. KG, Nordrhein-Westfalen, Germany). NDF and ADF were determined according to the methods of [18] by using a Fibretherm FT 12 fibre analyser (C. Gerhardt GmbH \& Co. KG, Nordrhein-Westfalen, Germany). Calcium in the basal diet was determined using an atomic absorption spectrophotometer (GBC, GBC932, Braeside VIC, Australia), and dietary phosphorus was determined by the colorimetric method.

\subsection{Statistical Analyses}

Dry matter intake (DMI) and milk production were calculated as an average per cow over the experimental period. Statistical analyses of DMI, milk production, and digestibility data were performed using the mixed procedure of SAS (1999) (SAS Institute Inc., Cary, NC, USA). Statistical analyses of milk composition were performed with repeated measures for sampling time referring to the mixed procedure of SAS [19] with a model including treatment, time, and time $\times$ treatment. Orthogonal polynomial contrasts were used to evaluate the linear and quadratic effects of APG supplementation levels. Significance was declared at $p \leq 0.05$, and a tendency was declared at $0.05 \leq p \leq 0.10$.

\section{Results}

As shown in Table 2, there was no significant difference in the DMI and milk yield with the addition of APG to diets. However, the milk yield in the APG supplement groups was numerically higher than that in the control. For milk composition, milk fat content had a quadratic response $(p=0.04)$, lactose content $(p=0.07)$ and lactose yield $(p=0.01)$ increased linearly, and protein content had an increasing quadratic trend $(p=0.10)$ with increasing APG levels. In addition, the milk protein yield, SNF yield and TS yield were significantly influenced by the addition of APG $(p<0.05)$, as they increased linearly ( $p=0.03, p=0.01, p=0.01$, respectively) as APG supplementation increased. The milk lactose yield increased linearly $(p=0.01)$ with increasing APG levels. Remarkably, milk fat yield was significantly associated $(p=0.03)$ with APG supplementation and exhibited quadratic growth $(p=0.01)$ with increasing levels of APG supplementation. The milk fat yield of the APG11 group was higher $(p<0.05)$ than that of the other groups. The lactose yield in APG22 group was significantly higher than that in APG0 group $(p<0.05)$. Cows in the APG11 and APG22 groups had greater $(p<0.05)$ milk protein, SNF and TS yields than cows in the APG0 group.

Table 2. Effects of APG supplementation on the lactating performance of cows.

\begin{tabular}{|c|c|c|c|c|c|c|c|c|}
\hline \multirow{2}{*}{ Item $^{1}$} & \multicolumn{4}{|c|}{ Treatment $^{2}$} & \multirow{2}{*}{ SEM } & \multicolumn{3}{|c|}{$p$-Value ${ }^{3}$} \\
\hline & APG0 & APG5.5 & APG11 & APG22 & & $\mathrm{T}$ & $\mathbf{L}$ & $\mathbf{Q}$ \\
\hline DMI $^{4}$ & 11.0 & 11.3 & 11.1 & 11.2 & 0.14 & 0.65 & 0.60 & 0.71 \\
\hline Milk yield & 14.0 & 15.2 & 16.3 & 16.7 & 1.17 & 0.42 & 0.14 & 0.50 \\
\hline \multicolumn{9}{|l|}{ Yield $(\mathrm{g} / \mathrm{d})$} \\
\hline Fat & $460.6^{b}$ & $540.7^{\mathrm{ab}}$ & $649.5^{\mathrm{a}}$ & $547.5^{\mathrm{ab}}$ & 38.55 & 0.03 & 0.13 & 0.01 \\
\hline Protein & $412.8^{c}$ & $465.5^{\mathrm{bc}}$ & $560.0^{\mathrm{a}}$ & $513.1^{\mathrm{ab}}$ & 30.76 & 0.02 & 0.03 & 0.03 \\
\hline Lactose & $653.4^{b}$ & $706.4^{\mathrm{ab}}$ & $767.6^{\mathrm{ab}}$ & $819.0^{a}$ & 41.23 & 0.06 & 0.01 & 0.57 \\
\hline SNF & $1216.5^{b}$ & $1333.3^{\mathrm{ab}}$ & $1504.2^{\mathrm{a}}$ & $1524.3^{\mathrm{a}}$ & 72.31 & 0.02 & 0.01 & 0.19 \\
\hline TS & $1636.6^{b}$ & $1825.0^{\mathrm{ab}}$ & $2091.0^{a}$ & $2013.6^{a}$ & 97.41 & 0.02 & 0.01 & 0.05 \\
\hline \multicolumn{9}{|c|}{ Composition (\%) } \\
\hline Fat & 3.29 & 3.58 & 4.02 & 3.29 & 0.26 & 0.19 & 0.96 & 0.04 \\
\hline Protein & 2.96 & 3.07 & 3.46 & 3.06 & 0.18 & 0.25 & 0.62 & 0.10 \\
\hline Lactose & 4.67 & 4.65 & 4.70 & 4.89 & 0.09 & 0.25 & 0.07 & 0.40 \\
\hline SNF & 8.71 & 8.78 & 9.25 & 9.10 & 0.24 & 0.34 & 0.18 & 0.37 \\
\hline TS & 11.7 & 12.0 & 12.9 & 12.0 & 0.43 & 0.29 & 0.54 & 0.11 \\
\hline
\end{tabular}

${ }^{1} \mathrm{DMI}=$ dry matter intake; SNF = solid non-fat; TS = total solid. Data of milk composition and component yields shown are the mean of values on $\mathrm{d} 20,40$ and 60 . Means within a row with different superscripts are different at $p<0.05 .{ }^{2}$ APG $=$ alkyl polyglycoside; APG0, APG5.5, APG11, APG22 = add 0, 5.5, 11 and $22 \mathrm{~mL} \mathrm{APG} \mathrm{per} \mathrm{kg} \mathrm{pelleted} \mathrm{concentrate} \mathrm{on} \mathrm{a} \mathrm{DM} \mathrm{basis,}$ respectively. ${ }^{3} \mathrm{~T}=$ treatment; $\mathrm{L}=$ linear; $\mathrm{Q}=$ quadratic. Means with different letters within a row differ significantly $(p<0.05)$. ${ }^{4} \mathrm{DMI}=$ pelleted concentrate + distillers grains + limpograss. The pelleted concentrate, distillers grains, and limpograss were fed separately. Each dairy cow was fed equal amounts of pelleted concentrate $(4.5 \mathrm{~kg}$ DM/cow) and distillers grains $(2.1 \mathrm{~kg} \mathrm{~kg} \mathrm{DM} / \mathrm{cow})$ daily; A sufficient amount of limpograss was fed to each cow every day and the intake of limpograss was recorded. 
Blood index results in Table 3 show that BHB, AMM, TG, TC, LDL-C, and HDL-C in serum were not influenced by APG supplementation. However, in response to the increasing level of dietary APG supplementation in cows, the concentration of serum glucose showed a decreasing tendency (quadratic, $p=0.06$ ).

Table 3. Effects of APG supplementation on the blood index of lactating cows.

\begin{tabular}{|c|c|c|c|c|c|c|c|c|}
\hline \multirow{2}{*}{ Item $(\mathrm{mmol} / \mathrm{L})^{1}$} & \multicolumn{4}{|c|}{ Treatment $^{2}$} & \multirow{2}{*}{ SEM } & \multicolumn{3}{|c|}{$p$-Value ${ }^{3}$} \\
\hline & APG0 & $\mathrm{T}$ & APG11 & APG22 & & $\mathrm{T}$ & $\mathbf{L}$ & $\mathbf{Q}$ \\
\hline GLU & 1.94 & 1.75 & 1.49 & 1.82 & 0.15 & 0.21 & 0.59 & 0.06 \\
\hline BHB & 0.29 & 0.29 & 0.29 & 0.30 & 0.02 & 0.93 & 0.63 & 0.71 \\
\hline AMM & 0.06 & 0.06 & 0.59 & 0.06 & 3.21 & 0.96 & 0.88 & 0.95 \\
\hline BUN & 3.83 & 3.49 & 3.65 & 3.96 & 0.24 & 0.53 & 0.49 & 0.26 \\
\hline TG & 0.91 & 1.27 & 1.31 & 2.41 & 0.68 & 0.46 & 0.14 & 0.74 \\
\hline TC & 2.44 & 2.35 & 1.92 & 2.36 & 0.32 & 0.62 & 0.84 & 0.29 \\
\hline LDL-C & 2226.7 & 2028.7 & 1721.1 & 2142.6 & 292.6 & 0.64 & 0.85 & 0.24 \\
\hline HDL-C & 2.13 & 2.10 & 1.87 & 2.15 & 0.22 & 0.76 & 0.99 & 0.40 \\
\hline
\end{tabular}

${ }^{1} \mathrm{GLU}=$ glucose; $\mathrm{BHB}=$ beta-hydroxybutyrate; $\mathrm{AMM}=$ ammonia; $\mathrm{BUN}=$ urea nitrogen; $\mathrm{TG}$ = triglyceride; $\mathrm{TC}=$ total cholesterol; LDL-C $=$ low-density lipoprotein cholesterol; HDL-C $=$ high-density lipoprotein cholesterol. ${ }^{2}$ APG = alkyl polyglycoside; APG0, APG5.5, APG11, APG22 = 0, 5.5, 11 and $22 \mathrm{~mL}$ APG per kg of pelleted concentrate on a DM basis, respectively. ${ }^{3} \mathrm{~T}=$ treatment; $\mathrm{L}=$ linear; $\mathrm{Q}=$ quadratic.

In the present work, we also demonstrated that the apparent digestibility of $\mathrm{CP}, \mathrm{EE}$, crude ash, OM, NDF, and ADF (Table 4) in dietary diets was not influenced by APG supplementation.

Table 4. Effects of APG supplementation on digestibility in lactating cows.

\begin{tabular}{cccccccccc}
\hline \multirow{2}{*}{ Item (\%) $^{\mathbf{1}}$} & \multicolumn{4}{c}{ Treatment $^{\mathbf{2}}$} & \multirow{2}{*}{ SEM } & \multicolumn{3}{c}{$p$-Value $^{\mathbf{3}}$} \\
\cline { 2 - 4 } \cline { 7 - 9 } & APG0 & APG5.5 & APG11 & APG22 & & T & L & Q \\
\hline CP & 74.3 & 71.1 & 74.8 & 74.7 & 2.43 & 0.67 & 0.65 & 0.71 \\
EE & 82.6 & 81.3 & 82.1 & 83.1 & 2.18 & 0.94 & 0.76 & 0.67 \\
Crude ash & 41.3 & 38.1 & 43.1 & 38.3 & 5.41 & 0.88 & 0.81 & 0.81 \\
OM & 68.6 & 64.1 & 68.5 & 67.1 & 2.94 & 0.69 & 0.98 & 0.76 \\
NDF & 59.3 & 53.6 & 59.1 & 55.8 & 3.92 & 0.71 & 0.77 & 0.89 \\
ADF & 45.8 & 41.5 & 49.2 & 44.6 & 4.44 & 0.65 & 0.92 & 0.78 \\
\hline
\end{tabular}

${ }^{1} \mathrm{CP}=$ crude protein; $\mathrm{EE}=$ ether extract; $\mathrm{OM}=$ organic matter; $\mathrm{NDF}=$ neutral detergent fibre; $\mathrm{ADF}=$ acid detergent fibre.

${ }^{2} \mathrm{APG}=$ alkyl polyglycoside; APG0, APG5.5, APG11, APG22 = 0, 5.5, 11 and $22 \mathrm{~mL}$ APG per kg of pelleted concentrate on a $\mathrm{DM}$ basis, respectively. ${ }^{3} \mathrm{~T}=$ treatment; $\mathrm{L}=$ linear; $\mathrm{Q}=$ quadratic.

\section{Discussion}

The research involving NIS in areas of livestock production has mainly focused on Tween 80 , and there are a few studies on the application of APG and other NIS. In the present work, we found that the addition of APG in diets had no significant influence on the DMI of dairy cows, which is similar to the report of Kim et al. [20], who found no effect of dietary NIS (sorbitan trioleate) supplementation (50 mL/day/head) on the DMI of cows during the transition period. We estimate that due to the physical properties of APG, including good wettability, low interfacial tension [21,22], and temperature insensitivity [8], the palatability of the diet is not changed and the feed consumption is not affected in dairy cows.

Previously, Helmer et al. [15] and Bezeau et al. [16] found that the NIS poloxalene had no effect on milk yield. Kim et al. [20] demonstrated that average milk production of dairy cows in the first six weeks postpartum was not affected by the dietary supplementation of NIS (mainly sorbitan trioleate) compared with the control group. In the present study, although the average milk yield in the APG supplementation groups was numerically greater, there was no statistically significant difference in the average milk yield between the APG supplementation groups and the control group. The results appear to justify that supplementing APG in quantities up to $99 \mathrm{~mL}$ per day does not deleteriously 
affect dairy animals. Considering the relatively low number of animals used in this study, further studies are needed to explore the effect of APG on dairy cow performance.

In our study, APG supplementation in the diets increased milk fat and milk protein yields. This supported a study by Kim et al. [20], who found that NIS supplementation significantly increased the milk fat percentage by approximately $3.9 \%$ in cows. It has been speculated that increasing milk fat content by NIS supplementation might be related to the influences of NIS on rumen microflora [20] since rumen fermentation products, such as acetate (a primary milk fat precursor) and butyrate, are used by the cow for energy and by the mammary glands to produce milk fat [23]. Moreover, NIS have been shown to have an impact on rumen fermentation and the rumen microbial population [6,24-27]. On the other hand, our previous study indicated that the proportions of ruminal amino acids, such as valine, phenylalanine and lysine, were affected by the dietary APG supplementation in goats [14]. The amino acid profile in the rumen, especially the amino acid composition of microbial crude protein, have a close relationship with the protein and amino acid compositions of milk [28,29]. Therefore, the effects of dietary APG supplementation on milk fat and protein yield in the current study might be related to influencing the ruminal microbiota and amino acid composition. Unfortunately, we did not measure in vivo rumen fermentation and ruminal microbiota. However, this speculation contradicts the results that dietary APG inclusion did not affect nutrient digestibility in the study. So, the reason for how the APG affected the lactation performance is not clear, and further studies with a larger sample size and the measurement of fermentation characteristics and rumen microbiome need to be performed to shed more light on this occurrence.

For the blood index, there was no difference in BHB, AMM, BUN, TG, TC, LDL-C, and HDL-C in serum by dietary treatment, while the concentration of serum glucose showed a decreasing tendency as dietary APG supplementation increased. A previous study by our research group demonstrated that plasma urea and glucose concentrations in goats were not affected by dietary APG supplementation (13 mL daily per animal) [14]. Similarly, Hristov et al. [30] found that Tween 80 did not influence plasma glucose and urea concentrations in steers fed a diet containing $70 \%$ barley. In addition, Lee et al. [25] reported that the blood glucose values of dairy cows from 21 days prepartum through 42 days postpartum were also not affected by the addition of Tween 80 .

For the apparent digestibility of $\mathrm{CP}, \mathrm{EE}$, crude ash, OM, NDF, and ADF, dietary APG supplementation had no significant influence, which is inconsistent with our hypothesis. In our prior study, dietary APG supplementation in goats increased the total tract digestibility of OM and NDF [13]. However, Chen et al. [31] reported that dietary supplementation with Tween 40,60 or 80 (10 g/day, respectively) did not affect the nutrient intake or digestion of sheep. The dietary addition of Tween 80 ( $5 \mathrm{~g} /$ day or $10 \mathrm{~g} /$ day) had no effect on the digestibility of DM, CP, NDF, ADF, and crude ash in Hanwoo steers [6]. In addition, Hristov et al. [30] and McAllister et al. [32] reported that the apparent digestibility of DM, $\mathrm{NDF}, \mathrm{ADF}$, and $\mathrm{CP}$ were not affected by dietary supplementation with Tween 80 in steers and lambs. The reports on the effects of NIS on nutrient digestibility in animals are inconsistent, although most of the existing studies showed that NIS had no effect on digestibility. The differences in the results of NIS on nutrient digestibility among studies were probably due to the experimental animals, experimental diets, NIS inclusion levels, NIS properties, etc. Thus, more studies are needed to investigate the effect of NIS on nutrient digestibility.

\section{Conclusions}

Dietary APG supplementation improved milk fat, milk protein, SNF and TS outputs in lactating dairy cows; no negative responses in milk production, digestibility, and blood metabolites were observed. This implies that APG has potential as a feed additives to improve lactation performance in middle and low yielding dairy cattle. Further studies are needed to explore the mode of action of APG in dairy cows, as well as the influence of APG on ruminal fermentation, microbial communities, and interfacial nutrient metabolism of ruminal microbes. 
Author Contributions: Conceptualization, D.W., S.T., Z.T. and X.H.; Data curation, S.T.; Formal analysis, X.Z. and X.H.; Investigation, X.Z., C.J. and Q.G.; Methodology, D.W.; Supervision, Z.T. and X.H.; Writing-original draft, X.Z.; Writing-review \& editing, X.H.

Funding: This work was financially supported by the National Key Research and Development Program of China (Grant No. 2018YFD0501604), the Open Project Program of Key Laboratory of Tarim Animal Husbandry Science and Technology, the Xinjiang Production \& Construction Group (Grant No. HS201508), and the Major Project for Science and Technology of Hunan Province (Grant No. 2017NK1020).

Conflicts of Interest: The authors declare no conflict of interest.

\section{References}

1. Helle, S.S.; Duff, S.J.B.; Cooper, D.G. Effect of surfactants on cellulose hydrolysis. Biotechnol. Bioeng. 1993, 42, 611-617. [CrossRef] [PubMed]

2. Yazdi, M.T.; Woodward, J.R.; Radford, A. The cellulase complex of neurospora-crassa - activity, stability and release. J. Gen. Microbiol. 1990, 136, 1313-1319. [CrossRef] [PubMed]

3. Kim, M.H.; Lee, S.B.; Ryu, D.D.Y.; Reese, E.T. Surface deactivation of cellulase and its prevention. Enzyme Microb. Tech. 1982, 4, 99-103. [CrossRef]

4. Kamande, G.M.; Baah, J.; Cheng, K.J.; McAllister, T.A.; Shelford, J.A. Effects of Tween 60 and Tween 80 on protease activity, thiol group reactivity, protein adsorption, and cellulose degradation by rumen microbial enzymes. J. Dairy Sci. 2000, 83, 536-542. [CrossRef]

5. Hristov, A.N.; Ivan, M.; Neill, L.; McAllister, T.A. Evaluation of several potential bioactive agents for reducing protozoal activity in vitro. Anim. Feed Sci. Tech. 2003, 105, 163-184. [CrossRef]

6. Kim, C.H.; Kim, J.N.; Ha, J.K.; Yun, S.G.; Lee, S.S. Effects of dietary addition of surfactant Tween 80 on ruminal fermentation and nutrient digestibility of Hanwoo steers. Asian Austral. J. Anim. 2004, 17, 337-342. [CrossRef]

7. Wang, F.; Zhang, Y.Q. Effects of alkyl polyglycoside (APG) on Bombyx mori silk degumming and the mechanical properties of silk fibroin fibre. Mat. Sci. Eng. C-Mater. 2017, 74, 152-158. [CrossRef] [PubMed]

8. Pakpayat, N.; Nielloud, F.; Fortune, R.; Tourne-Peteilh, C.; Villarreal, A.; Grillo, I.; Bataille, B. Formulation of ascorbic acid microemulsions with alkyl polyglycosides. Eur. J. Pharm. Biopharm. 2009, 72, 444-452. [CrossRef]

9. Zhao, J.W.; Yang, Q.; Li, X.M.; Wang, D.B.; Luo, K.; Zhong, Y.; Xu, Q.X.; Zeng, G.M. Enhanced production of short-chain fatty acid from food waste stimulated by alkyl polyglycosides and its mechanism. Waste Manag. 2015, 46, 133-139. [CrossRef]

10. Liao, Z.J.; Du, S.N.; Luo, Y.; Zuo, F.; Luo, J.B. Use of liquid crystal to study the interactions of alkyl polyglycosides with gelatin and bovine serum albumin. Chin. Chem. Lett. 2016, 27, 852-856. [CrossRef]

11. ElMeshad, A.N.; Tadros, M.I. Transdermal delivery of an anti-cancer drug via w/o emulsions based on alkyl polyglycosides and lecithin: design, characterization, and in vivo evaluation of the possible irritation potential in rats. Aaps. Pharmscitech 2011, 12, 1-9. [CrossRef]

12. Cong, Z.H.; Tang, S.X.; Tan, Z.L.; Sun, Z.H.; Zhou, C.S.; Han, X.F.; Wang, M.; Ren, G.P. Effects of different nonionic surfactants on in vitro fermentation characteristics of cereal straws. J. Anim. Sci. 2009, 87, 1085-1096. [CrossRef]

13. Yuan, Z.Q.; Tang, S.X.; Zeng, B.; Wang, M.; Tan, Z.L.; Sun, Z.H.; Zhou, C.S.; Han, X.F.; Bamikole, M.A. Effects of dietary supplementation with alkyl polyglycoside, a nonionic surfactant, on nutrient digestion and ruminal fermentation in goats. J. Anim. Sci. 2010, 88, 3984-3991. [CrossRef]

14. Zeng, B.; Tan, Z.L.; Tang, S.X.; Han, X.F.; Tan, C.Y.; Zhong, R.Z.; He, Z.X.; Arigbede, O.M. Effects of alkyl polyglycoside, a nonionic surfactant, and forage-to-concentrate ratio on rumen fermentation, amino acid composition of rumen content, bacteria and plasma in goats. Arch. Anim. Nutr. 2011, 65, 229-241. [CrossRef]

15. Helmer, L.G.; Bartley, E.E.; Meyer, R.M. Bloat in Cattle.9. Effect of poloxalene used to prevent legume boat on milk production feed intake health reproduction and rumen fermentation. J. Dairy Sci. 1965, 48, 575-579. [CrossRef]

16. Bezeau, L.M.; Clark, R.D.; Gray, R.J. Poloxalene as an anti-bloat compound and its effect on milk yield and composition. Can. J. Comparat. Med. 1967, 31, 352-353.

17. AOAC. Official Methods of Analysis of AOAC, International 18th ed.; USA Association of Analytical Communities: Gaithersburg, MD, USA, 2005; Animal Feed section 1-6. 
18. Vansoest, P.J.; Wine, R.H. Method for Determination of Lignin Cellulose and Silica. J. Anim. Sci. 1967, 26, 940.

19. Littell, M.J.; Lawry, J.; Bowden, G.H.; Switalski, L.M. Recognition of collagen type I by Actinomyces naeslundii strains. J. Dent. Res. 1996, 75, 613.

20. Kim, H.S.; Ahn, B.S.; Chung, S.G.; Moon, Y.H.; Ha, J.K.; Seo, I.J.; Ahn, B.H.; Lee, S.S. Effect of yeast culture, fungal fermentation extract and non-ionic surfactant on performance of Holstein cows during transition period. Anim. Feed Sci. Tech. 2006, 126, 23-29. [CrossRef]

21. VonRybinski, W. Alkyl glycosides and polyglycosides. Curr. Opin. Colloid Interface Sci. 1996, 1, $587-597$. [CrossRef]

22. Iglauer, S.; Wu, Y.F.; Shuler, P.; Tang, Y.C.; Goddard, W.A. Alkyl polyglycoside surfactant-alcohol cosolvent formulations for improved oil recovery. Colloid Surf. A 2009, 339, 48-59. [CrossRef]

23. Duffield, T.; Bagg, R.; Kelton, D.; Dick, P.; Wilson, J. A field study of dietary interactions with monensin on milk fat percentage in lactating dairy cattle. J. Dairy Sci. 2003, 86, 4161-4166. [CrossRef]

24. Ha, J.K.; Lee, S.S.; Goto, M.; Moon, Y.H.; Cheng, K.J. Influence of tween 80 on the enzyme distribution in rumen liquor and on the growth of rumen bacteria and fungi. J. Appl. Anim. Res. 2002, 21, 129-143. [CrossRef]

25. Lee, S.S.; Ahn, B.H.; Kim, H.S.; Kim, C.H.; Cheng, K.J.; Ha, J.K. Effects of non-ionic surfactants on enzyme distributions of rumen contents, anaerobic growth of rumen microbes, rumen fermentation characteristics and performances of lactating cows. Asian Austral. J. Anim. 2003, 16, 104-115. [CrossRef]

26. Ruiz, D.R.Y.; Moumen, A.; Garcia, A.I.M.; Alcaide, E.M. Ruminal fermentation and degradation patterns, protozoa population, and urinary purine derivatives excretion in goats and wethers fed diets based on two-stage olive cake: Effect of PEG supply. J. Anim. Sci. 2004, 82, 2023-2032. [CrossRef]

27. Hatami, A.; Alipour, D.; Hozhabri, F.; Tabatabaei, M. Effect of different levels of pomegranate marc with or without polyethylene glycol on performance, nutrients digestibility and protozoal population in growing lambs. Anim Feed Sci. Tech. 2018, 235, 15-22. [CrossRef]

28. Schwab, C.G.; Bozak, C.K.; Whitehouse, N.L.; Olson, V.M. Amino-acid limitation and flow to the duodenum at 4 stages of lactation.2. extent of lysine limitation. J. Dairy Sci. 1992, 75, 3503-3518. [CrossRef]

29. Sinclair, K.D.; Garnsworthy, P.C.; Mann, G.E.; Sinclair, L.A. Reducing dietary protein in dairy cow diets: Implications for nitrogen utilization, milk production, welfare and fertility. Anim. 2014, 8, 262-274. [CrossRef]

30. Hristov, A.N.; McAllister, T.A.; Olson, M.E.; Cheng, K.J.; Yanke, L.J.; Shelford, J.A. Effect of Tween 80 and salinomycin on ruminal fermentation and nutrient digestion in steers fed a diet containing $70 \%$ barley. Can. J. Anim. Sci. 2000, 80, 363-372. [CrossRef]

31. Chen, Y.; Zhang, H.L.; Wang, H.Y.; Yang, K.L. Effects of dietary addition of non-ionic surfactants on ruminal metabolism and nutrient digestion of Chinese Merino sheep. Asian J. Anim. Vet. Adv. 2011, 6, 688-696. [CrossRef]

32. McAllister, T.A.; Stanford, K.; Bae, H.D.; Treacher, R.J.; Hristov, A.N.; Baah, J.; Shelford, J.A.; Cheng, K.J. Effect of a surfactant and exogenous enzymes on digestibility of feed and on growth performance and carcass traits of lambs. Can. J. Anim. Sci. 2000, 80, 35-44. [CrossRef]

(C) 2019 by the authors. Licensee MDPI, Basel, Switzerland. This article is an open access article distributed under the terms and conditions of the Creative Commons Attribution (CC BY) license (http://creativecommons.org/licenses/by/4.0/). 